\title{
Analisa terhadap Kebijakan Fiskal dan Moneter Indonesia dalam Menghadapi Wabah Pandemi Covid-19
}

\author{
Hertinawati $^{1}$ \\ ${ }^{1}$ Magister Manajemen Universitas Ahmad Dahlan Yogyakarta, hertinafriend@gmail.com
}

\section{ARTICLES INFORMATION}

ABSTRACT

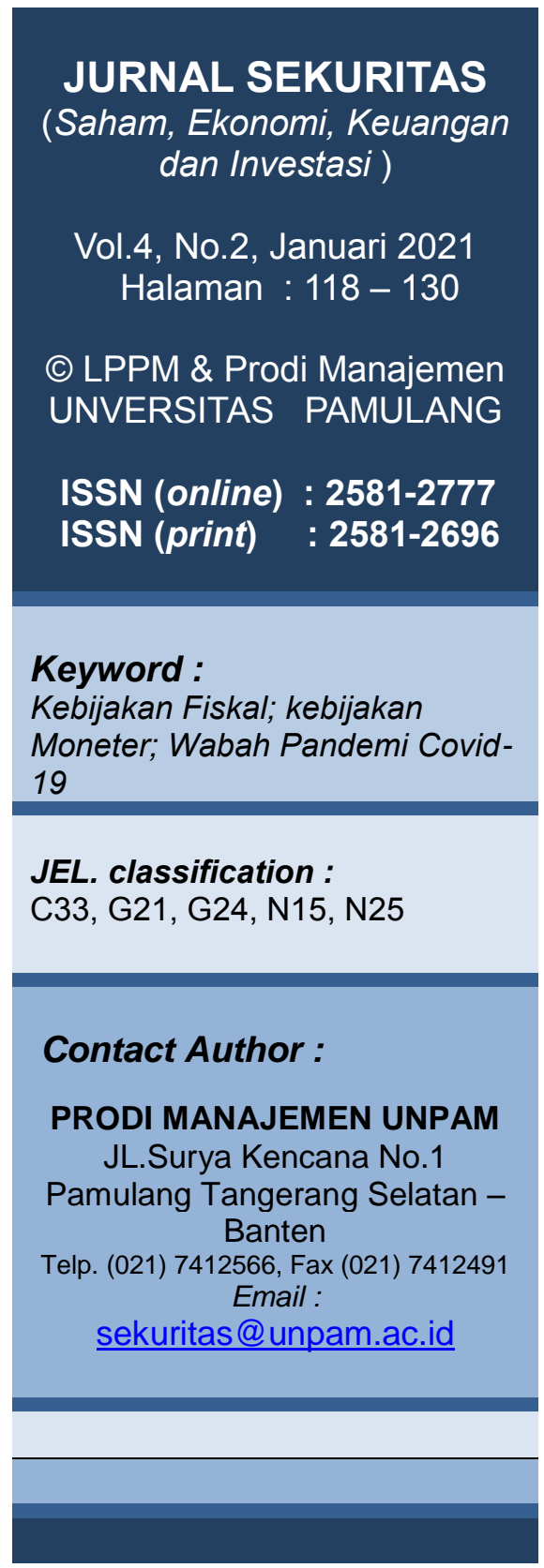

Penelitian ini bertujuan untuk melakukan analisa tentang kebijakan kebijakan fiskal, dan moneter Indonesia dalam upaya mengantisipasi dampak perekonomian yang diakibatkan dari pandemi Covid-19 terhadap pengaruh yang lebih besar terhadap perkonomian nasional Indonesia. Penelitian ini menggunakan metode penelitian kualitatif deskriptif yaitu metode untuk memahami berbagai konsep yang ditemukan dalam proses penelitian, dengan teknik analisis isi dan riset kepustakaan. Hasil penelitian menunjukkan bahwa berbagai upaya pemerintah Indonesia, yaitu kebijakan moneter yang diperlukan dalam rangka menstabilkan system perekonomian dengan mendukung kebijakan fiscal oleh lembaga moneter nasional, yatu Bank Indonesia dan juga didukung aktif oleh peran badan Otoritas Jasa Keuangan di Indonesia. Dalam hal ini pemerintah Indonesia tengah telah berupaya menjalankan kombinasi kebijakan-kebijakan tersebut agar dapat mengentaskan Bangsa Indonesia dari krisis ekonomi yang lebih besar.

This study aims to conduct an analysis of Indonesia's fiscal and monetary policies in an effort to anticipate the economic impact resulting from the Covid-19 pandemic on a greater impact on Indonesia's national economy. This study uses descriptive qualitative research methods, namely methods to understand various concepts found in the research process, with content analysis techniques and library research. The results show that the various efforts of the Indonesian government, namely the monetary policy needed in order to stabilize the economic system by supporting fiscal policy by the national monetary institution, namely Bank Indonesia, are also actively supported by the role of the Financial Services Authority in Indonesia. In this case, the Indonesian government is trying to implement a combination of these policies in order to save the Indonesian nation from a bigger economic crisis. 


\section{A. PENDAHULUAN}

Corona virus termasuk keluarga besar jenis virus yang menjadi penyebab penyakit yang menyerang hewan dan juga manusia. Pada manusia, ada beberapa jenis virus corona yang telah diketahui dapat menjadi penyebab dari infeksi pada system pernafasan mulai gejala flu ringan sampai penyakit serius seperti Sindrom Pernafasan Timur Tengah atau dikenal dengan penyakit MERS dan SARS. Virus corona ini adalah yang menjadi penyebab penyakit corona virus COVID-19. (WHO, 2020)

Covid-19 mewabah ke seluruh dunia, berawal dari kasus local di Wuhan, China yang pada akhirnya menyebar dengan cara penularan dari luar wilayah asal, atau disebut kasus impor yaitu penularan melalui transmisi local yang terjadi antar penduduk. Kasus yang terjadi untuk pertama kalinya berkaitan dengan Covid-19 pada saat ini belum memberikan informasi yang menyeluruh tentang virus ini.

Katadata.com dalam laporannya menulis tentang penyebaran virus corona hingga memasuki bulan Juni sudah mencapai 28,3 ribu kasus di seluruh dunia. Jumlahnya paling banyak di Tiongkok, yakni 28 ribu kasus. Sisanya tersebar di negara-negara Asia, Eropa, dan Amerika, juga di Australia dan Uni Emirat Arab.Virus memaikan ini sudah menyebar di 28 negara. Sedangkan pemerintah Indonesia mengkonfirmasi dua kasus pasien positif Covid-19 pertama Pada 2 Maret 2020. (Pranita:2020)

Data yang diperoleb dari learnbonds.com, virus novel corona (2019-nCo V) menjadi epidemi termahal dalam 20 tahun terakhir .Tercatat kerugian ekonorni akibat virus yang menyerang sebagian daratan Tiongkok, yang merupakan daerab pertama yang mengumumkan terjangkit Covid-19 ini, diproyeksikan mencatat kerugian sebesar US\$ 62 miliar .Angka ini lebih besar dari kerugian ekonomi dari Ebola yang senilai US\$ 53 miliar.

Perekonomian Tiongkok melemah akibat penyebaran virus corona ini. Padahal, produlk: domestik bruto (PDB) global selama ini disumbang sebanyak $17 \%$ dari Tiongkok, yang secara otomatis adanya gangguan perekonomiannya dapat dirasakan oleh Negara lain. Paling terdampak adalah Hong Kong, yang diperkirakan mengalami penurunan pertumbuhan ekonomi $1,74 \%$. Selanjutnya Korea Selatan $(0,41 \%)$, Brasil $(0,32 \%)$, Australia $(0,29 \%)$ dan Indonesia $(0,26 \%)$ pada tahun 2020.

Suryahadi menyarnpaikan bahwa pelemahan ekonomi karena Covid-19 akan meningkatkan jumlah penduduk miskin di Indonesia. Dampak yang lebih buruk, jika ekonorni hanya tumbuh $1 \%$, akan mengakibatkan $12,4 \%$ tingkat kemiskinan di Indonesia. Angka kamiskinan ini meningkat disbanding tahun 2019 sebesar 9,2\%, sehingaa implikasinya untuk membantu masyaralk:at miskin baru diperlukan program perlingungan sosial. (Suryahadi, 2020)

Menurut kementrian keuangan, dalam Surat Perintah, SP - $27 / \mathrm{KLI} / 2020$, sejalan dengan adanya perturan PSBB dan WFH, Pemerintah mengeluarkan kebijakan dalam system perpajakan yaitu dengan pemberlakuan relaksasi pembayaran PPh Pasal 29 OP dan pelaporan SPT PPh OP, yang berakibat pada ketidakoptimalan realisasi pendapatan Negara dari PPh Pasal 29 OP. Terlebih lagi, pendapatan Negara bersumber dari Kepaeanan dan Cukai secara nominal dari penerimaan Cukai dan Bea Masuk (BM), tumbuh mencapai angka 23,60\% (yoy), bersumber dari jumlah pendapatan Cukai dengan pertumbuhan 36,50\% (yoy). Sedangkan dari sisi realisasi penerimaan Bea Keluar kumulatif akan mengalami pertumbuhan yang negatif $32,56 \%$ (yoy). Hal ini disebabkan oleh turunnya volume impor, sehingga terjadi kontraksi pada pertumbuhan penerimaan dari sektor pajak perdagangan internasional, hal ini menyebabkan penurunan harga komoditas, dan juga terjadi perlambatan kegiatan ekspor barang mentah sebagai akibat dari penyebaran Virus Covid19.

Peran kebijakan fiscal dalam stabilisasi sector ekonomi di suatu negara memang tidak terpisahkan dari kebijakan moneter. Cazacu (2015:12). Nainggolan dalam situs www.djkn.kemenkeu.go.id, menyatakan bahwa kebijakan yang menyeluruh di bidang fiskal 
maupun di bidang moneter telah diambil oleh pemerintah Indonesia untuk mengatasi wabah Covid-19. Di bidang fiskal, kebijakan memfokuskan kembali kegiatan serta refisi pengalokasian anggaran juga telah dilakukan Pemerintah. Presiden Joko Widodo, telah menerbitkan Inpres No.4/2020, tentang instruksi kepada semua jajaran kementrian serta para pimpinan termasuk di dalamnya para pejabat di tingkat daerah untuk mempercepat pemfokusan kembali kegiatan, realokasi anggaran juga dalam pengadaan barang jasa hal ini merupakan upaya untuk menangani wabah Covid-19.

Paper ini terdiri dari empat bagian; yang pertama adalah pendahulan yaitu menjelaskan tentang dampak ekonomi secara umum terhadap negara oleh wabah Covid-19. Selanjutnya bagian kedua menjelaskan secara singkat tentang kajian literature tentang kebijakan perekonomian fiscal dan moneter. Pada bagian tiga menerangkan tentang metode kualitatif deskriptif yang digunakan dalam penulisan paper ini. selanjutnya, bagian empat akan menyampaikan analisis terhadap hasil serta pembahasan penelitian mengenai kebijakan fiskal serta kebijakan moneter yang diimplementasikan oleh pemerintah Indonesia. Pada bagian akhir paper ini akan disajikan kesimpulan yang berkaitan dengan hasil dan pembahasan.

\section{B. KAJIAN LITERATUR}

\section{Kebijakan Fiskal}

Teori Keynes telah menjadi dasar dari filosofi kebijakan ini muncul sebagai reaksi dari depresi besar yang terjadi pada sistem ekonomi Amerika di tahun 1930-an. Kritik yang disampaikan Keynes terhadap ahli ekonomi Klasik yang berpendapat bahwa perekonomian akan selalu full employment. Namun, sistem pasar bebas yang dikemukakan oleh Keynes tidak akan otomatis membuat penyesuaian kondisi pekerjaan penuh, karena diperlukan adanya campur tangan pemerintah dalam bentuk kebijakan pemerintah, yaitu kebijakan fiscal dan moneter. Dikarenakan, tiap tambahan belanja negara bukan hanya merelokasikan sumber daya dari sektor swasta kepada pemerintah, namun diikuti timbulnya multipliereffect atas belanja tersebut. (Mankew, 2013:303)

Teori angka pengganda fiskal yang disampaikan Keynes ini didasari oleh pemikiran bahwa ekspansi fiskal dapat menyebabkan dampak pengganda pada permintaan agregat yaitu kemampuan penawaran agregat dalam merespon kenaikan permintaan agregat, sehingga kenaikan harga tidak akan terjadi. (Abimanyu, 2005)

\section{Kebijakan Moneter}

Mankiw (2013:315) menyatakan bahwa focus dan tujuan dari kebijakan moneter dan fiscal itu memiliki perbedaan. Mentransmisikan variabel yang berbeda di dalam perekonomian pada setiap shock dari pelaksanaan kebijakan moneter dan fiskal. Jika pemerintah mengharapkan adanya pertumbuhan di sector ekonomi, ada beberapa kebijakan yang bisa dilakukan pemerintah, misalnya dengan menaikkan tingkat belanja pemerintah. Diharapkan dengan adanya peningkatan belanja pemerintah ini mendorong naiknya permintaan agregat, sehingga akan menyebabkan kenaikan harga barang. Dan ini akan menyebabkan terjadinya Inflasi akibat kenaikan permintaan yang melampaui jumlah penawaran. Dalam menghadapi tekanan inflasi ini, kebijakan moneter yang akan diambil BI adalah menaikkan suku bunga acuan. Hal ini dapat mengakibatkan defisit fiscal juga akan semakin besar pula, terlebih ketika pemerintah diharuskan membayar bunga hutangnya. Oleh karena focus kebijakan moneter berbeda dengan kebijakan fiscal, maka kedua kebijakan ini adalah dua kebijakan terkait. Hal ini seperti yang diungkapkan oleh Cacazu (2015: 12) yang menegaskan bahwa peran kebijakan fiskal dalam stabilisasi ekonomi suatu negara tak terpisahkan dari kebijakan moneter 


\section{METODOLOGI PENELITIAN}

Metodologi seperti yang disampaikan oleh Bogdan dan Taylor merupakan proses, prinsip, dan prosedur yang kita gunakan untuk mengamati masalah serta menemukan solusi. Perspektif teoritis dalam penelitian juga turut mempengaruhi metodologi, yaitu suatu kerangka pemikiran atau interpretasi penulis dalam memahami data dan hubungannya dengan peristiwa lain. Sedangkan kualitatif adalah pengumpulan data yang bersifat kualitatif, yaitu data yang diperoleh tanpa menggunakan alat ukur tertentu. Juga bersifat natural yaitu apa adanya, tidak direkayasa. (Nasution 2003: 18).

Bog dan dan Taylor (Moleong, 2010: 3) menyatakan kualitatif merupakan prosedur penelitian yang menghasilkan perkataan baik lisan maupun tulisan dari seseorang atau pelaku yang sedang kita amati."

Maka dapat diambil kesimpulan bahwa penelitian dengan pendekatan kualitatif maka sifat data yang dikumpulkan bercorak kualitatif, karena tidak menggunakan alat ukur tertentu, situasi lapangan bersifat "natural" atau wajar, sehingga diperoleh hasil penelitian yang deskriptif.

Penelitian ini menggunakan metode analisis isi, yaitu suatu cara untuk memperoleh penjelasan dari teks dalam bentung lambang. metode ini dapat digunakan semua bentuk komunikasi, baik media masa cetak maupun elektronik. Seiring kemajuan teknologi komunikasi dapat dilakukan dengan cara general inquirer program. Ide yang menjadikan analisisi isi sebagai sebuah metode ini muncul dari Bernard Berelson di tahun 1959 yang telah mencurahkan perhatian yang lebih pada metode analisis ini. (Rakhmat, Jalaludin, 1999)

Sedangkan metode kajian pustaka adalah merupakan teori yang sesuai dengan masalah yang sedang diteliti. Yaitu adanya kajian tentang konsep yang digunakan berdasarkan referensi yang ada, terutama dari artikel dalam karya ilmiah. Kajian pustaka ii ditujukan untuk merangkum konsep yang dijadikan landasan pemikiran dalam sebuah penelitian.( V.Wiratna Sujarweni, 2014)

\section{HASIL DAN PEMBAHASAN}

Pandemi Covid-19 menjadi wabah yang menyebar hingga 199 negara di dunina. Semua Negara dengan sigap mengambil langkah yang cepat dalam menghambat laju penyebaran Covid-19 karena akan memberi dampak pada seluruh aspek kehidupan, bukan hanya dalam bidang kesehatan yang terpuruk namun juga membawa dampak di bidang social maupun ekonomi masyarakat yang semakin parah.

\section{Dampak Kesehatan Covid-19}

Covid-19 adalah virus yang dapat menyebar dengan cepat walaupun tidak cukup mematikan seperti halnya virus $\mathrm{H} 2 \mathrm{~N} 1$ dan DBD, namun dapat berbahaya bagi penderita lanjut usia dan pasien dengan riwayat penyakit bawaan seperti jantung, dan penyakit gula serta pasien dengan riwayat penyakit gangguan pernapasan akut.

Hingga awal bulan Januari 2021, jumlah terkonfirmasi Covid-19 di seluruh dunia adalah 86,5 juta jiwa dengan kasus meninggal 1, 87 juta jiwa, menurut laporan WHO. Negara yang paling banyak terinfeksi seluruh dunia adalah Amerika serikat, India, Brazil, Rusia dan Inggris, Prancis dan Italia. 
Tabel 1. Persebaran Kasus Covid- 19 di dunia

\begin{tabular}{|c|c|c|c|c|}
\hline Name & $\begin{array}{l}\text { Cases-cumulative } \\
\text { total } \equiv !\end{array}$ & $\begin{array}{l}\text { Cases - newiy } \\
\text { reported in last } 24 \\
\text { hours }\end{array}$ & $\begin{array}{l}\text { Deaths - cumulative } \\
\text { total }\end{array}$ & $\begin{array}{l}\text { DEखण I5 - newIy } \\
\text { reported in last } 24 \\
\text { hours }\end{array}$ \\
\hline Global & $84,474,195$ & 541,811 & $1,848,704$ & 8,696 \\
\hline E- United States 0 & $20,470,169=$ & 211,444 & 348,962 & 1.407 \\
\hline India & $10,356,844=$ & 16,375 & 149,850 & 201 \\
\hline (9) Brazil & $7,733,746=$ & 17,341 & 196,018 & 293 \\
\hline Russian Feder. & $3,284,384=$ & 24.246 & 59,506 & 518 \\
\hline SIT The United Kin. & $2,713,567=$ & 58,784 & 75,431 & 407 \\
\hline I Erance & $2,615,185=$ & 3,569 & 65,035 & 376 \\
\hline Italy & $2,166,244=$ & 10,798 & 75,680 & 348 \\
\hline
\end{tabular}

\section{Sumber : WHO Coronavirus Disease (COVID-19) Dashboard}

Sedangkan Indonesia berada pada posisi 20 besar dunia dari total kasus positif Covid19 dengan total kasus 780 ribu jiwa. Dengan kasus terbanyak terjadi di Pulau Jawa meliputi wilayah DKI Jakarta, Jawa timur, Jawa Tengah dan Jawa Barat. (Arnani, Mela. 2020)

\section{Dampak Sosial Covid-19}

Upaya memutus mata rantai penyebaran Covid-19 yaitu dengan menjaga jarak sosial, hal ini ditujukan untuk menanggulangi penyebaran virus dengan jarak tertentu. Menurut Pusat Kontrol dan Pencegahan Penyakit (CDC) di AS, social distancing adalah menghindari perkumpulan dan bertemunya masa serta menjaga jarak social sejauh 2 meter. Termasuk didalamnya terdapat kebijakan untuk bekerja, belajar dan beribadah dari rumah.

Social distancing ini berpengaruh sangat besar dalam kehidupan social masyarakat Indonesia yang terkenal sangat guyup (sebagai contoh ketika merayakan acara pernikahan, adanya kegiatan upacara adat atau acara kumpul bersama keluarga besar dan teman sejawat misalnya). Semenjak merebaknya virus Covid-19 ini tentu hal ini sudah tidak dapat dilakukan lagi.

\section{Dampak Ekonomi Covid-19}

Adanya pandemi Covid-19 yang paling besar dampaknya adalah pada sektor ekonomi. Hal ini nampak pada proyeksi pemerintah bahwa perekonomian Indonesia tumbuh -0,4-2,3\% pada 2020. Namun demikian pada tahun 2021, pemerintah Indonesia tetap optimis bahwa perekonomian diperkirakan meningkat 4,5-5,5\%. Berbagai institusi keuangan dunia memberikan proyeksi pertumbuhan perekonomian ekonomi Indonesia untuk tahun 2020 hingga 2023. Berbagai penelitian memperkirakan COVID-19 akan menurunkan laju pertumbuhan perekonomian Indonesia menjadi antara 1 dan 4 persen. (Suryahadi, 2020:11) 


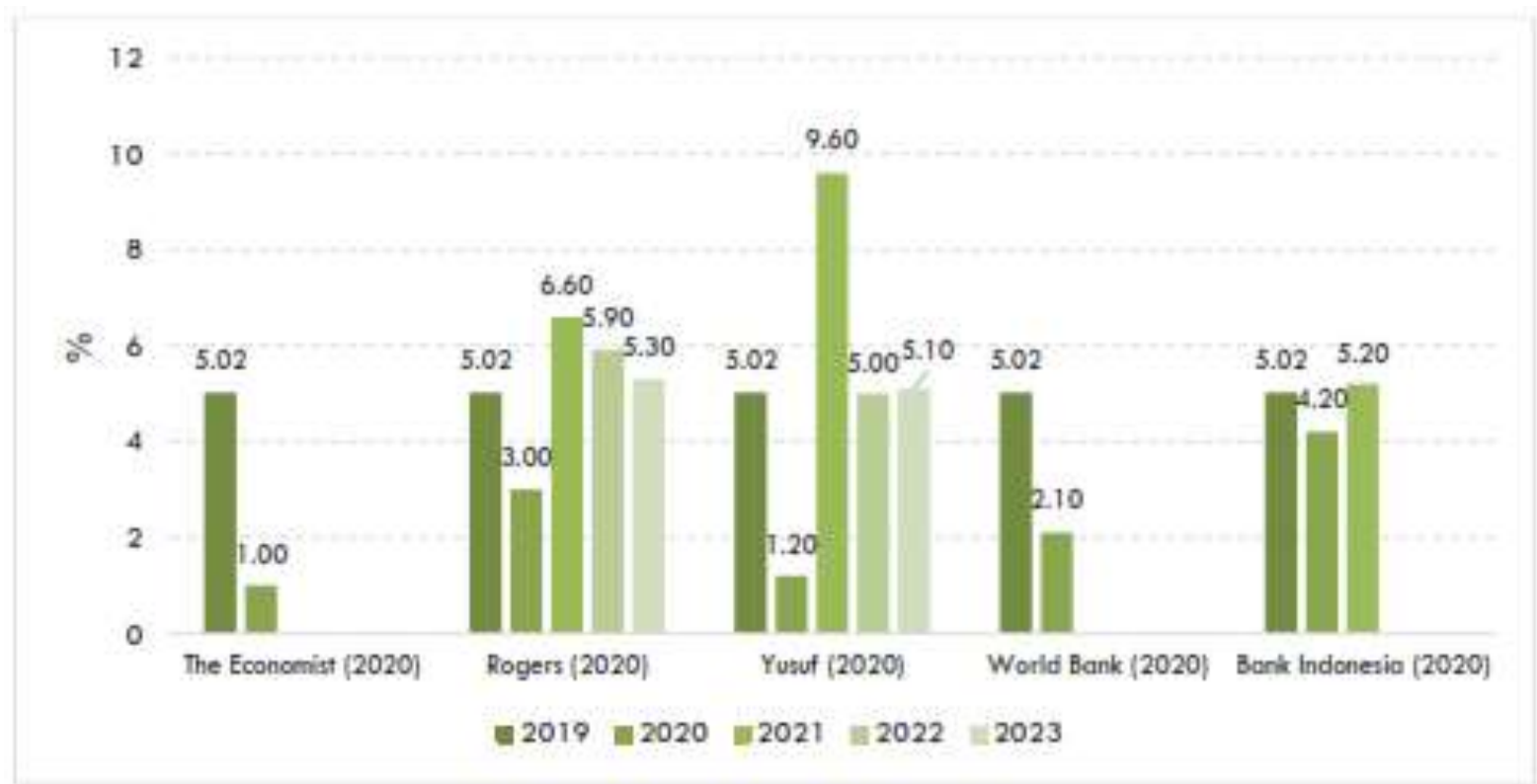

Gambar. 1. Proyeksi pertumbuhan ekonomi Indonesia pada 2020-2023

Sumber. Suryahadi, et all (2020)

Kementerian Keuangan melalui Badan Kebijakan Fiskal (BKF) juga memproyeksikan bahwa pertumbuhan tigkat pengangguran dan masyarakat miskin akan meningkat selama wabah Covid-19. Tiga proyeksi kenaikan yang telah disusun oleh Febrio Nathan Kacaribu, selaku pimpinan BKF, antara lain pada perhitungan dasar (normal), berat dan sangat berat. yaitu diperkirakan tingkat dasar, diproyeksikan pengangguran terbuka (TPT) sebesar $5,18 \%$, hingga $9,02 \%$ dan kemiskinan pada angka $9,18 \%$ sampai $10,98 \%$ pada perhitungan sangat berat.

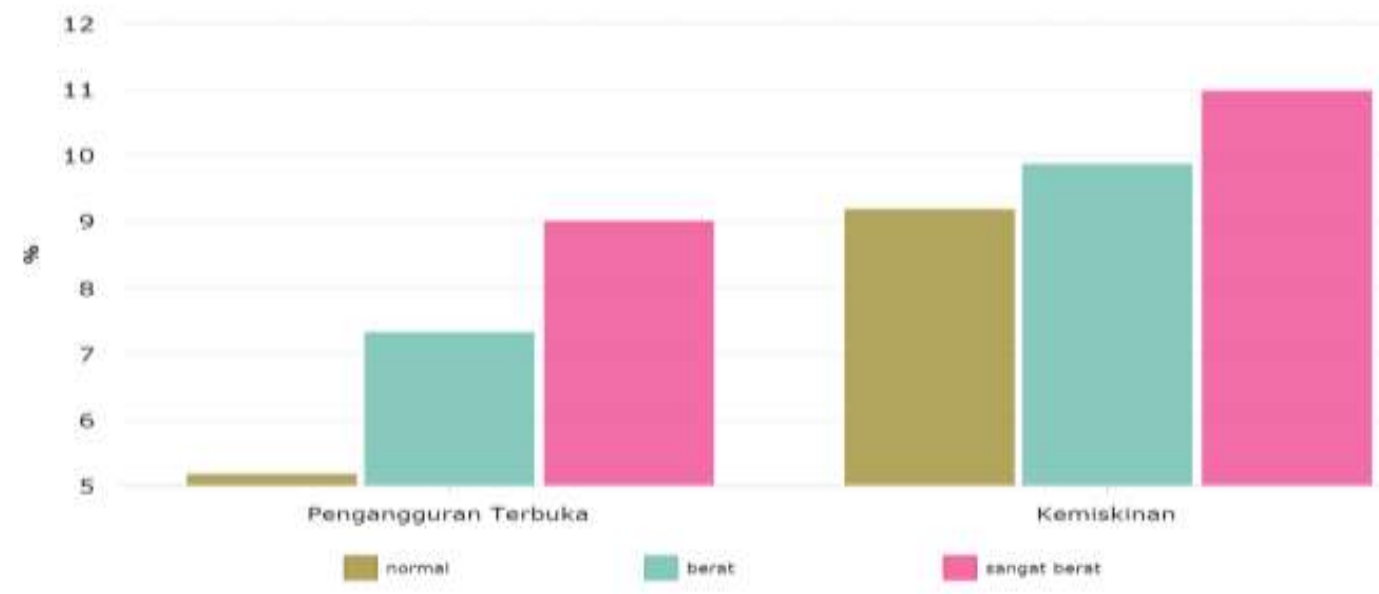

D katadata

Gambar 2. Proyeksi Pengangguran dan Kemiskinan Indonesia 2020

Sumber : katadata.co.id

BKF Kemenkeu membuat sejumlah proyeksi peningkatan angka kemiskinan pada tahun 2020, yang terjadi akibat Pandemi Covid-19 saat ini. Angka kemiskinan yang terjadi di Pulau Jawa akan meningkat sangat pesat, diperkirakan jumlah penduduk miskin di Pulau Jawa bisa bertambah menjadi 2,75 juta jiwa. Sumatra, bertambah menjadi 1,11 juta, di Sulawesi meningkat 300 ribu jiwa. Selanjutnya Bali serta Nusa Tenggara dan Kalimantan, 
250 ribu jiwa. Sedangkan di Maluku dan Papua diprediksi akan bertambah hingga 190 ribu jiwa penduduk miskin.

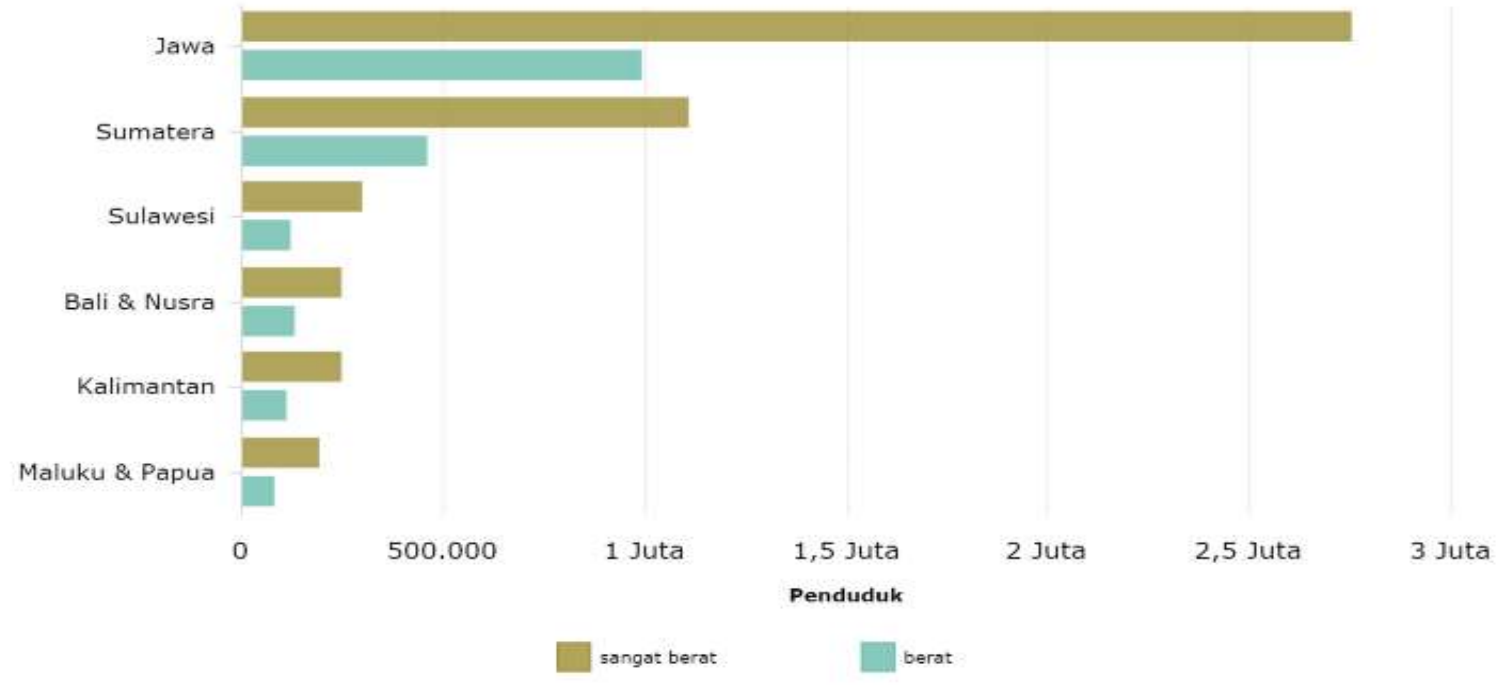

D katadata

Gambar 3. Peningkatan Penduduk Miskin Akibat Covid-19

Sumber : katadata.co.id

COVID-19 juga memberikan dampak pada perubahan rata-rata pengeluaran rumah tangga per kapita antara tahun 2019 dan 2020, diperkirakan turun -1,17 menjadi -2,88 persen bila masing-masing pertumbuhan pada tahun 2020 diproyeksikan sebesar 4.2 dan 3 persen,. Namun, penurunan tersebut akan jauh lebih tinggi sebesar $-4.16,-5.44$, dan -5.72 persen ketika pertumbuhan pada tahun 2020 diproyeksikan jauh lebih lambat pada masingmasing 2,1, 1,2, dan 1 persen. Suryahadi, et all (2020: 8)

Tabel 2. Hasil Estimasi rata-rata pengeluaran pendapatan per kapita Rumah Tangga Tahun 2020

\begin{tabular}{|ccccc}
\hline Growth 2019 & $\begin{array}{c}\text { Growth 2020 } \\
\text { (Scenario) }\end{array}$ & $\begin{array}{c}\text { Change } \\
2010-2020\end{array}$ & $\begin{array}{c}\text { Coefficient of } \\
\text { correlation }\end{array}$ & $\begin{array}{c}\text { Change in } \\
\text { Avarage PCE }\end{array}$ \\
\hline $5.02 \%$ & $4.20 \%$ & $-0.82 \%$ & 1.424 & $-1.17 \%$ \\
\hline $5.02 \%$ & $3.00 \%$ & $-2.02 \%$ & 1.424 & $-2.88 \%$ \\
\hline $5.02 \%$ & $2.10 \%$ & $-2.92 \%$ & 1.424 & $-4.16 \%$ \\
\hline $5.02 \%$ & $1.20 \%$ & $-3.82 \%$ & 1.424 & $-5.44 \%$ \\
\hline $5.02 \%$ & $1.00 \%$ & $-4.02 \%$ & 1.424 & $-5.72 \%$ \\
\hline
\end{tabular}

Sumber : Suryahadi, et all (2020)

Menurut Herlambang dalam situs https://www.ayosemarang.com, ada tiga regulasi yang telah dikeluarkan pemerintah dalam rangka melawan dampak ekonomi dan social dari pandemic Covid-19. Ketiga regulasi tersebut adalah: pertama, Perppu No. 1 Tahun 2020 mengenai kebijakan keuangan dan PP No. 21 Tahun 2020 serta Kepres No. 11 Tahun 2020 tentang peraturan Pembatasan Berskala Besar dan darurat kesehatan di masa pandemic Covid-19. 
Para ekonom masih tetap mewaspadai kemungkinan terburuk kerugian yang akan terjadi akibat meningkatnya pengangguran yang disebabkan oleh kebijakan lockdown dari pemerintah tersebut, karena orang-orang tidak keluar rumah untuk melakukan aktifitas produksi dan distribusi. (Partington \& Wearden, 2020). Hikmah dapat kita ambil dari pemerintah Tiongkok telah berhasil dan sigap dalam mengambil tindakan langsung terhadap dalam penanganan Covid-19, yaitu bahwa sebagai pengambil kebijakan yang terdepan, pemerintah tidak boleh terhambat dengan kurangnya dana. Seperti penyediaan unit-unit perawatan intensif dan juga kapasitas rumah sakit juga harus diperluas; pembangunan rumah sakit sementara; serta alat penunjang kesehatan seperti respirator dan masker hendaknya diproduksi secara massal dan tersedia bagi masyarakat yang membutuhkan. Di sisi lain, lembaga kesehatan hendaknya diberikan sumber daya serta dana yang dibutuhkan untuk melakukan disinfeksi ruang-ruang public. Hal yang paling urgen untuk dilakukan pada saat pandemic Covid-19 saat ini adalah menjaga dan meningkatkan kualitas kebersihan lingkungan. Perlu juga dilakukan identifikasi setiap kasus yang ada, karena hal ini merupakan upaya yang dapat menyelamatkan banyak nyawa. ( Sikki, 2020:13).

\section{Implementasi Kebijakan Fiskal Indonesia}

Implementasi kebijakan Fiskal di Indonesia berdasar PERPU Nomor. 1 Tahun 2020 mengenai Kebijakan dan Stabilitas Sektor Keuangan Negara yang berlaku sejak 31 Maret 2020, antara lain:

1. Penetapan batas deficit Anggaran Negara diatas 3\% dari PDB pada periode penanganan COVID-19 sampai tahun fiscal 2022 dan deficit akan kembali pada angka paling tinggi sebesar 3\% pada 2023

2. Adanya penyesuaian tariff pajak, antara lain:

a. Pajak pendapatan perusahaan sebesar $22 \%$ pada 2020 dan 2021 , menjadi $20 \%$ di tahun 2022

b. Pajak Penghasilan Badan Terbuka untuk Publik dengan kriteria jumlah saham yang disetor dapat diperjualbelikan paling sedikit sebesar $40 \%$ dengan persyaratan tertentu, akan dengan tariff pajak 3\% lebih rendah dari pajak penghasilan pada poin $2 a$

3. Kemudahan dalam pelaksanaan pajak yaitu:

a. Kebijakan pengajuan keringanan pajak akan diperpanjang hingga 6 bulan

b. Masa pengembalian pajak hingga kurun waktu 1 tahun

c. Waktu jatuh tempo tentang klaim pengembalian pajak, keberatan pajak, pengurangan atau penghapusan sanksi pajak diperpanjang dalam waktu 6 bulan.

4. Pembebasan kepabeanan dan cukai terhadap barang import yang terkait dengan pegembangan industry Dalam Negeri.

Komitmen pemerintah Indonesia adalah terus menjaga kontinuitas fiscal di tahun 2020. Adanya defisit APBN sampai dengan bulan April 2020 sebesar Rp74,47 triliun hal ini setara dengan 0,44 \% PDB. Sedangkan pembiayaan sampai April 2020 sejumlah Rp221,84 triliun hal ini meningkat sebesar 53,58 \% (yoy), yang bersumber dari pembiayaan utang.

Sentimen negatif pasar keuangan terjadi pada awal bulan Maret lalu akibat situsi yang tidak pasti akibat pandemi Covid-19. Namun demikian situasi pasar uang dinilai mulai stabil sejak April meskipun masih tetap harus dipantau volatilitasnya. Pemerintah juga telah menerbitkan SUN dalam global bonds di bulan yang sama. Hal ini dilakukan sebagai suatu strategi pembiayaan APBN 2020 dalam rangka menunjang biaya yang terjadi akibat pandemic Covid-19.

Selanjutnya pemerintah juga mensinergikan BI dalam SKB No 190/KMK.08/2020 antara Menteri Keuangan dan Gubernur BI, mengantisipasi situasi yang dapat membahayakan stabilitas keuangan Indonesia akibat pandemic Covid-19. Dalam SKB tersebut BI dapat membeli SBN jangka panjang dan bersifat tradable pada pasar perdana. Yang dilaksanakan 2 tahap, yaitu pada rangkaian lelang SBSN dan SUN tanggal 21 dan 28 
April 2020. Selain itu Pemerintah memperkenalkan adanya Pemulihan Ekonomi Nasional (PEN) dalam PP nomor 23 tahun 2020, hal ini merupakan upaya memberdayakan UMKM

Adanya Pandemi Covid-19 yang sukar diprediksi menyebabkan lemahnya system perekonomian Indonesia. Namun demikian pemerintah tetap menempatkan kebijakan fiscal untuk menjaga kestabilan perekonomi Indonesia. Proyeksi pemerintah terhadap angka defisit APBD melebar 6,27 persen terhadap PDB. Agar terpenuhi kebutuhan belanja Negara utamanya dengan prioritas penanganan Covid-19 dan untuk dalam rangka pemulihan perekonomian akibat pandemic Covid-19, pemerintah perlu tetap mengutamakan prinsip kehati-hatian, akuntabel serta transparan. (Puspasari, Rahayu, 2020)

\section{Analisa Mengenai Kebijakan Fiskal}

Berbagai penelitian telah dilakukan untuk menganalisa kebijakan fiscal yang dilakukan pemerintah saat ini. Sebuah study yang telah dilakukan antara lain tentang fleksibilitas pajak sebagai intrumen kebijakan fiscal untuk menghadapi krisi yang diakibatkan oleh pandemic Covid 19. Adiananta (2020) menjelaskan kesuksesan bangsa Indonesia sebagai Negara yang lepas dari krisis ekonomi dengan strategi kebijakan fiskal yang cukup baik dan juga telah berhasil melakukan reformasi peraturan dan sistem perpajakan modern. Pengalaman ini menjadi pelajaran yang penting bagi Pemerintah dalam rangka pembuatan kebijakan dalam rangka antisipasi terhadap dampak finansial dan moneter akibat wabah Covid-19, menyimpulkan bahwa: a) Pajak sebagai instrument kebijakan fiskal dengan fungsi mengatur serta menjaga stabilitas perekonomian negara yang diakibatkan adanya kontraksi dan relaksasi ekonomi, yang fleksibel dari sisi peneriman negara yang berkelanjutan; b) Kebijaksanaan fiskal yang berhasil meningkatkan daya saing investasi dan sebagai upaya antisipasi melemahanya perekonomian global sebagai akibat dari pandemi Covid-19 dengan mengoptimalkan fungsi dari alokasi anggaran belanja negara yang seimbang.

Studi lain juga dilakukan oleh Silalahi, et all (2020: 156) mengenai kebijakan fiskal pemerintah, yang menekankan kebijakan pemerintah dari kedua sisi baik dari sisi penerimaan dan pengeluaran. Dalam rangka mencapai target penerimaan negara dilakukan dengan cara revisi terhadap target penerimaan atas pajak, realokasi pendapatan pada APBN 2020 dan melakukan digitalisasi pajak. Di sisi pengeluaran negara, pemerintah akan melakukan revisi anggaran dalam rangka mengurangi deficit APBN. Tiga tahapan stimulus anggaran yang dilakukan pemerintah yang pertama di bulan Februari sebesar Rp 8,5 triliun untuk memperkuat perekonomian negara dari sector pariwisata, dan $\mathrm{Rp} 22,5$ triliun yang dianggarkan pada bulan Maret. Kebijakan fiskal dan nonfiskal hal ini ditujukan untuk mendorong sector industri juga mempermudah eksporimpor dan dikucurkan dana Rp. 405 triliun pada akhir bulan Maret sebagai dana kebijakan kesehatan.

Dengan diterapkannya kebijakan fiscal terhadap pendapatan dan belanja negara untuk menjaga pertumbuhan dan kestabilan ekonomi. Di sisi penerimaan, hendaknya pemerintah lebih memperhatikan dalam kontribusi pendapatan terutama yang didapat dari PPN dan $\mathrm{PPh}$. Pemerintah harus memberi perhatian dari aspek realisasi penggunaan dana dari sisi pengeluaran, agar dana tersebut tepat sasaran dan memfokuskan kegiatan pada prioritas untuk mencegah merebaknya wabah Covid-19. Sedang dalam rangka menekan defisit anggaran dari berbagai pembiayan yang dilakukan oleh pemerintah dengan cara merevisi/ refocusing terhadap APBN agar dapat dioptimalkan penggunaannya pada masa merebaknya wabah Covid-19. (Silalahi, et all. 2020:166)

\section{Implementasi Kebijakan Moneter Indonesia}

Dalam UU No. 23 tahun 1999 tentang Bank Indonesia (BI), yaitu mengenai fungsi BI dalam menjaga kestabilan moneter dan juga menjaga kestabilan keuangan dan kedua hal ini sangat terkait dan menunjang dalam upaya menstabilkan nilai rupiah. (Sabirin, 2020)

Bank Indonesia sebagai lembaga yang menetapkan kebijakan moneter negara, tertuang dalam PERPU No 1 Tahun 2020 yaitu dengan memberikan wewenang kepada 
Bank Indonesia untuk: memberi pinjaman likuiditas jangka pendek baik kepada bank baik sistemik maupun selain bank sistemik. Memberi akses penyaluran dana pada sector swasta melalui repo utang Pemerintah melalui perbankan. Menerima pengajuan pinjaman likuiditas khusus jika bank sistemik yang sebelumlah telah menerima pinjaman likuiditas jangka pendek namun masih mengalami kesulitan likuiditas kepada BI.

Selain kebijakan BI diatas, Pemerintah juga akan mengatur program penjaminan selain program penjaminan simpanan dengan menerbitkan peraturan pemerintah untuk mencegah krisis system keuangan yang lebih dalam.

Otoritas Jasa Keuangan (OJK) dalam situs resminya, menyatakan bahwa OJK telah merespon kondisi perekonomian Indonesia saat ini yaitu dengan diterbitkannya Peraturan OJK No. 11/PJOK. 03/2020, mengenai stimulus terhadap perekonomian nasional sebagai kebijakan counter cyclical dari dampak penyebaran Covid-19. Kebijakan ini berlaku untuk seua lembaga keuangan konvensional maupun syariah dan berlaku hingga 31 Maret 2021.

Kebijakan OJK tersebut antara lain: mendukung diterapkannya kebijakan-kebijakan oleh Bank yang dapat memberikan rangsangan terhadap pertumbuhan ekonomi debitur dan UMKM yang terdampak oleh penyebaran COVID-19 serta yang mengalami kesulitan untuk memenuhi kewajiban pada Bank, kebijakan-kebijakan antara lain: menilai kualitas kredit meningkatkan kualitas pembiayaan dan mengtur tentang penilaian kualitas aset. Penyaluran Kredit lain yang baru oleh Bank kepada debitur dengan perlakuan khusus sesuai POJK. Serta melakukan pelaporan berkala oleh Bank sejak akhir April 2020.

OJK juga memberi perintah pada lembaga jasa keuangan untuk dapat melakukan penggabungan, konsolidasi atau konversi, pengecualian kewajiban beberapa lembaga keuangan untuk melakukan pengungkapan di pasar modal, ketetapan terhadap ketentuan untuk teknologi informasi dan terahir tentang sanksi yang diberikan kepada orang-orang yang sengaja mengabaikan atau menghalangi kewenangan OJK dengan hukuman minimal 4 hingga 12 tahun penjara serta denda sebesar Rp 10 hingga 300 Miliar. Dan bagi perusahaan yang melakukan pelanggaran, maka dihukum dengan denda minimum 1 trilyun.

\section{Analisa Mengenai Kebijakan Moneter}

Penelitian ini menyimpulkan bahwa tingkat sentimen investor yang rendah terhadap pasar yang akhirnya dapat membawa pasar ke arah yang cenderung negatif merupakan dampak yang terjadi akibat pandemi COVID-19 ini membawa dampak pada fluktuasi ekonomi dengan pergerakan yang negatif. Beberapa langkah strategis di bidang fiscal dan moneter sangat dibutuhkan diharapkan dapat memberikan rangsangan terhadap perekonomian. Perlambatan ekonomi global yang signifikan terjadi terhadap perekonomian Indonesia terutama akibat dari penurunan kegiatan ekspor Indonesia ke China. Hal ini berdasarkan analisis sensitivitas yang menjelaskan bahwa pertumbuhan perekonomian Indonesia sangat terdampak akibat adanya perlambatan ekonomi global yang terjadi saat ini. (Nasution, et all (2020: 212)

Modjo (2020:103) menyatakan bahwa akibat mempertahankan kebijakan pembatasan juga akan berdampak pada berlanjutnya derita ekonomi yang panjang, yang tidak dapat tertolong sekalipun dengan berbagai insentif dan stimulus telah digelontorkan pemerintah. Disisi lain dengan tidak melaksakan utuk menjaga jarak social juga akan berisiko dalam menambah yang besar terhadap kesehatan masyarakat dan juga akan semakin menambah jumlah korban akibat virus Covid-19. Sehingga dalam fase new normal di Indonesia, berbagai institusi pemerintah, dalam hal ini Bappenas, telah menyiapkan satu Protokol kesehatan yang Aman bagi masyarakat dalam beraktivitas sosial ekonomi di masa Pandemi, sesuai kriteria WHO. Menyusun skala penanganan yang tepat dalam merefleksikan kebutuhan dan keberpihakan kepada masyarakat kecil, dalam hal ini menjadi golongan masyarakat yang paling terdampak Covid-19, dalam melakukan penanganan dan intervensi sosial ekonomi secara langsung perlu dilakukan penguatan basis data. Roadmap yang disusun hendaknya mempertimbangkan aspek kewilayahan secara mutlak. Lebih 
memperhatikan kekhasan wilayah karena adanya heterogenitas pengaruh yang ditimbulkan dari Wabah Covid-19, mengingat adanya keunggulan komparatif yang berbeda yang dimiliki berbagai wilayah di Indonesia.

Berdasarkan penelitian yang dilakukan SMERU Riseach Institute (2020:11), Indonesia hendaknya menyiapkan program perlindungan sosial yang dapat membantu orang miskin baru selain orang miskin yang sudah ada. Selain kareana besarnya sumber daya yang diperlukan dalam mengatasi masalah ini maka untuk memastikan efektivitas sosial tersebut program perlindungan, Indonesia perlu mempelajari kembali dari pengalaman pada program serupa pada krisis yang terdahulu serta pembelajaran penanganan yang dilakukan di negara lain.

\section{E. KESIMPULAN}

Upaya untuk mengatasi dampak pandemik Covid-19 ini, Pemerintah perlu menerapkan berbagai kebijakan fiscal pada pendapatan dan pengeluaran negara dalam rangka menjaga pertumbuhan dan kestabilan perekonomian Indonesia. Di sisi pendapatan, hal yang perlu diperhatikan oleh pemerintah adalah tentang optimalisasi kontribusi dari sisi pendapatan pemerintah, terutama yang bersumber baik dari PPN dan PPh. Termasuk didalamnya adalah dalam sistem perpajakan, strategi kebijakan fiskal yang dinamis serta memperbarui sistem perpajakan nasional melalui reformasi regulasi dan administrasi perpajakan modern. Di sisi pengeluaran, realisasi penggunaan dana penanganan Covid-19 ini agar tepat sasaran dengan prioritas pencegahan pandemik Covid-19 harus lebih diperhatikan oleh pemerintah. Pemerintah perlu menekan defisit anggaran dengan melakukan revisi terhadap anggaran yang tersusun dalam APBN agar penggunaannya lebih optimal selama masa pandemic Covid-19.

Menyusun prioritas penanganan yang tepat dalam merefleksikan kebutuhan serta keberpihakan kepada masyarakat kecil yang paling terdampak, serta memperkuat basis data untuk mengatasi dan terlibat secara langsung pada sector sosial ekonomi, juga dengan lebih memperhatikan comparative advantage yang dimiliki setiap daerah di Indonesia, dengan heterogenitas dampak yang terjadi akibat pandemic Covid-19 ini. Selain belajar dari pengalaman bangsa Indonesia dalam mengalami krisis perkonomian yang lalu, hendaknya bangsa Indonesia juga meninjau langkah-langkah kebijakan perekonomian dari Negaranegara lain.

\section{DAFTAR PUSTAKA}

Abimanyu, Anggito. (2005). Kebijakan Fiskal dan Efektivitas Stimulus Fiskal di Indonesia Aplikasi Model Makro MODFI dan CGE-INDORANI. Jurnal Ekonomi Indonesia, Vol 1, No. 1: 1-36

Adiyanta, FC.Susila. (2020). Fleksibilitas Pajak sebagai Instrumen Kebijaksanaan Fiskal untuk Mengantisipasi Krisis Ekonomi sebagai Akibat Dampak Pandemi Covid-19, Administrative Law \& Governance Journal. Volume 2 Issue 1: 162-181

Aksara, Bima. (2020). Rangkaian Peristiwa Pertama Covid-19, Bebas. Kompas.id. https://bebas.kompas.id/baca/riset/2020/04/18/rangkaian-peristiwa-pertama-covid-19/

Arnani, Mela (2020). Corona di Indonesia Tembus 200.000, Ini 5 Daerah dengan Jumlah Kasus Tertinggi dan Terendahi .

Kompas.com https://www.kompas.com/tren/read/2020/09/08/194500265/corona-diindonesia-tembus-200.000-ini-5-daerah-dengan-jumlah-kasus?page=all.

Bogdan, Robert dan Taylor. (1992) Pengantar Metode Penelitian Kualitatif, Terjemahan oleh Arief Rurchan, (Surabaya : Usaha Nasional). 
Cazacu, A. M. (2015). Fiscal-Monetary Policy Interaction. Svar Evidence From A Cee Country. European Scientific Journal, 45 (3), 1857 - 7881.

Hakim, L., Sunardi, N. (2017). Determinant of leverage and it's implication on company value of real estate and property sector listing in IDX period of 2011-2015. Man in India, 97(24), pp. 131-148.

Husain, T., \& Sunardi, N. (2020). Firm's Value Prediction Based on Profitability Ratios and Dividend Policy. Finance \& Economics Review, 2(2), 13-26.

Indonesia (2020). Surat Perintah, SP - 27 /KLI/2020: 1-5 Tentang: Pemerintah Waspada Dampak Pandemi Covid-19 Terhadap Ekonomi Indonesia.. Jakarta : Kementrian Keuangan

Indonesia. (2020). Perpu No. 1 tahun 2020 Tentang : Kebijakan Keuangan Negara dan Stabilitas Slstem Keuangan untuk Penanganan Pandemi Corona Virus Diseas 2019 (Covid-19) dan atau Dalam Rangka Menghadapi Ancaman yang Membahayakan Perekonomian Internasional dan/ atau Stabilitas SIstem Keuangan. Jakarta: Sekertariat Negara.

Kadim, A., Sunardi, N \& Husain, T. (2020). The modeling firm's value based on financial ratios, intellectual capital and dividend policy.Accounting, 6(5), 859-870.

Katadata.co.id (2020)

Mankiw, N. G. (2013). Macroeconomics Eight Edition. New York: Worth Publishers

Modjo, Mohamad Ikhsan. (2020). Memetakan Jalan Penguatan Ekonomi Pasca Pandemi, The Indonesian Journal of Development Planning, Vol IV No. 2 : hal. 103-116

Moleong, Lexy J. (2010), Metodologi penelitian kualitatif, Remaja Rosdakarya, Bandung

Nainggolan, Edward UP. (2020). Kebijakan Fiskal dan Moneter menghadapi Dampak Covid19 , djkn.kemenkeu.go.id. https://www.djkn.kemenkeu.go.id/artikel/baca/13017/Kebijakan-Fiskal-dan-MoneterMengadapi-Dampak-Covid-19.html.

Nardi Sunardi \& T. Husain \& A. Kadim, 2020. "Determinants of Debt Policy and Company's Performance," International Journal of Economics \& Business Administration (IJEBA), International Journal of Economics \& Business Administration (IJEBA), vol. 0(4), pages 204213.

Nardi Sunardi Et Al (2020). Determinants of Debt Policy and Company's Performance, International Journal of Economics and Business Administration Volume VIII Issue 4, 204-213

Nasution (2003) Metode Penelitian Naturalistik Kualitatif. Bandung. Tasrsito

Nasution, Dito Aditia et all. (2020). Dampak Pandemi Covid-19 terhadap Perekonomian Indonesia. Jurnal Benefita Vol. 5, No.2 :212-224

OJK. (2020) Tentang OJK ojk.co.id .. di : https://www.ojk.go.id/id/tentang-ojk/Pages/Tugasdan-Fungsi.aspx.

OJK. (2020). Ringkasan eksekutif Peraturan Otoritas Jasa Keuangan No. 11/PJOK. $03 / 2020$, tentang stimulus perekonomian nasional sebagai kebijakan countercyclical dampak penyebaran Covid-19 (PJOK Stimulus Dampak Covid-19). Pokok-pokok pengaturan POJK Stimulus Dampak COVID-19. Jakarta : OJK

Pranita, Ellyvon. (2020). Diumumkan Awal Maret, Ahli : Virus Corona Masuk Indonesia dari Januari, kompas.com.

https://www.kompas.com/sains/read/2020/05/11/130600623/diumumkan-awal-maretahli--virus-corona-masuk-indonesia-dari-januari. 
Puspasari, Rahayu. (2020) Kebijakan Fiskal Pemerintah Yang Pruden Dalam Menghadapi Pandemi, kemenkeu.go.id. https://www.kemenkeu.go.id/publikasi/siaran-pers/siaranpers-kebijakan-fiskal-pemerintah-yang-pruden-dalam-menghadapi-pandemi/

Rakhmat, Jalaludin. (1999). Metode Penelitian Komunikasi. Bandung: Rosdakarya hlm. 89

Sabirin, Syahril Dr. (2000) . Upaya Pemulihan Ekonomi Melalui Strategi Kebijakan Moneter_Perbankan dan Indepedensi Bank Indonesia. Makalah.: Seminar Nasional di KAGAMA Jawa Timur dan Perkumpulan untuk Peningkatan Usaha Kecil (PUPUK) Surabaya, 5 Februari.

Setiawan, Heru. (2018). Analisis Dampak Kebijakan dan Moneter terhadap Kinerja Makroekonomi di Indonesia dengan Model Structural Vector Autoregreassion (SVAR)". Jurnal IImu Ekonomi Terapan. Vol. 03, No. 2: 23-41

Sikki, Kaisar Lahiya. (2020). Kebijakan Ekonomi Arab Saudi dalam Mengantisipasi Pandemi Covid-19, Journal of Islamic Civilization. Volume 2, No. 1: 8-16

Silalahi, et all. (2020). Strategi Kebijakan Fiskal Pemerintah Indonesia dalam Menghadapi Dampak Pandemi COVID-19. Jesya : Jurnal Ekonomi \& Ekonomi Syariah Vol 3 No 2: 156-167

Sunardi, N., \& Lesmana, R. (2020). Konsep Icepower (Wiramadu) sebagai Solusi Wirausaha menuju Desa Sejahtra Mandiri (DMS) pada Masa Pandemi Covid-19. JIMF (Jurnal IImiah Manajemen Forkamma), 4(1).

Suryahadi, Asep et all. (2020). The Impact of Covid-19 Outbreak on Poverty : An Estimation for Indonesia. Smeru working Paper. The Smeru Research Institute, Jakarta.

V. Wiratna Sujarweni. (2014). Metodeologi Penelitian Yogyakarta : Pustaka Baru Perss. h.57.

WHO. (2020). Q\&A on Coronaviruses (COVID-19). Who.int. https://www.who.int/emergencies/diseases/novel-coronavirus-2019/question-andanswers-hub/q-a-detail/q-a-coronaviruses\#: :text=symptoms.

WHO. (2020). WHO Coronavirus Disease (COVID-19) Dashboard, covid-19.who.int. https://covid19. who.int/?gclid=CjOKCQjw6575BRCQARIsAMpksOTQFIFjoxhXSLH8v0SFJtdF-cWI5KbZm2I1leODA6sPCgWkxpCJlsaAijbEALw wcB. 